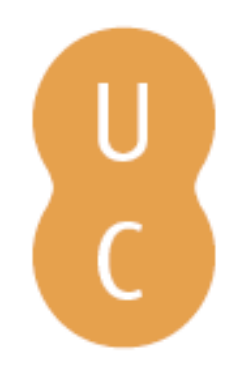

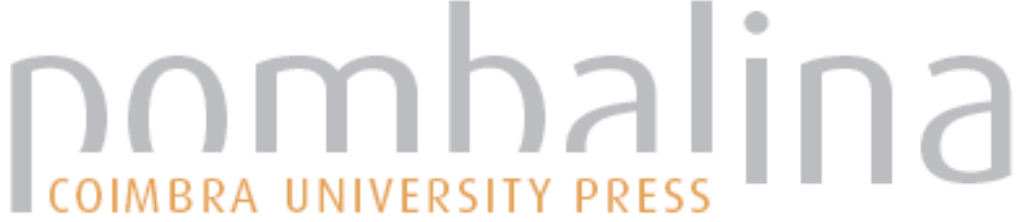

\section{A model for identifying blow-up fire potential}

Autor(es): $\quad$ McRae, Richard H. D.; Sharples, Jason J.; Badlan, Rachel L.

Publicado por: Imprensa da Universidade de Coimbra

URL

persistente: URI:http://hdl.handle.net/10316.2/44518

DOI: $\quad$ DOI:https://doi.org/10.14195/978-989-26-16-506_1

Accessed : $\quad$ 26-Apr-2023 07:38:48

A navegação consulta e descarregamento dos títulos inseridos nas Bibliotecas Digitais UC Digitalis, UC Pombalina e UC Impactum, pressupõem a aceitação plena e sem reservas dos Termos e Condições de Uso destas Bibliotecas Digitais, disponíveis em https://digitalis.uc.pt/pt-pt/termos.

Conforme exposto nos referidos Termos e Condições de Uso, o descarregamento de títulos de acesso restrito requer uma licença válida de autorização devendo o utilizador aceder ao(s) documento(s) a partir de um endereço de IP da instituição detentora da supramencionada licença.

Ao utilizador é apenas permitido o descarregamento para uso pessoal, pelo que o emprego do(s) título(s) descarregado(s) para outro fim, designadamente comercial, carece de autorização do respetivo autor ou editor da obra.

Na medida em que todas as obras da UC Digitalis se encontram protegidas pelo Código do Direito de Autor e Direitos Conexos e demais legislação aplicável, toda a cópia, parcial ou total, deste documento, nos casos em que é legalmente admitida, deverá conter ou fazer-se acompanhar por este aviso.

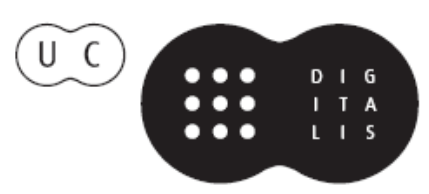




\section{ADVANCES IN}

\section{FOREST FIRE RESEARCH}

\section{8}

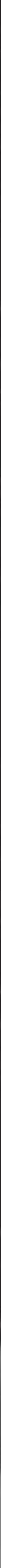




\title{
A model for identifying blow-up fire potential
}

\author{
Richard H.D. McRae ${ }^{1}$; Jason J. Sharples ${ }^{2 *}$; Rachel L. Badlan ${ }^{2}$ \\ ${ }^{1}$ ACT Emergency Services Agency, Canberra, Australia \\ ${ }^{2}$ School of Physical, Environmental and Mathematical Sciences; UNSW Australia \\ \{j.sharples@adfa.edu.au*\}
}

\begin{abstract}
Australia's fire services mitigate the risk to the community from wildfires in a manner that leaves minimal residual risk. This work is founded on forecasts of fire behaviour based on fuel, terrain and weather. Using steady-state fire behaviour equations, any given set of conditions permits a single expected fire behaviour prediction. Since 2001, Australia has been impacted with rapidly increasing frequency by a class of fires driven by a coupling of the fire with the atmosphere above the mixed layer. In their most extreme form, these fires produced pyroCbs. The continental climatology has four events in the satellite era up to 2001, but since then 56 further confirmed events. This change in frequency is considered to be due to climate change. Blowup events were seen to occur when a fire fire switches from normal linear flaming to areal flaming - over $5 \mathrm{~km}$ flaming depth has been observed. If this happens in an unstable atmosphere, the plume forms a cloud before it mixes out. The latent heat of condensation then released allows a rapid escalation of fire intensity on the surface. Arising from the extreme wildfires that hit Canberra on 18 January 2003, a series studies have shown how these fires develop. These insights were used to develop a predictive model for these events. The Blow Up Fire Outlook (BUFO) model incorporates these in a process model that has been formally trialled. An extreme wildfire is defined here as one where one or more blow-up events occur before it is suppressed. Deep flaming events are known to be caused by: two steady-state processes (strong winds and wind changes), a set of dynamic processes (vorticity-driven lateral spread, eruptive spread, dense spotting), inappropriate use of ignition devices, and reburning of areas as new fuel becomes flammable with time. The BUFO model was run in trial mode in the Australian Capital Territory and New South Wales over three summers. The results indicated that the trial was successful, despite the small sample size involved. The POD was $100 \%$, the FAR was $33 \%$ and the TNR was $100 \%$. The model utilised weather forecast data from the Bureau of Meteorology, weather observations, terrain analysis data from the HighFire Risk project (www.highfirerisk.com.au) and fire information. It makes heavy use of remotely-sensed information. The model is designed to start if there is an uncontained wildfire with raised fire danger, and to ask questions that are either true or false. The answers form a path that either loops back (for the model to be re-run at a different time) or yields a prediction of the potential for a blow-up fire event. Most of the nine questions are required to assess the potential for the formation of deep flaming. So, given that most of the damage is caused by fires not covered by the standard toolbox used by fire services, BUFO is designed to augment the work of Fire Behaviour Analysts. We are working to increase its uptake across the sector.
\end{abstract}

Keywords: Extreme wildfire, blow-up fire, dynamic fire spread, deep flaming, atmospheric instability, vorticity-driven lateral spread.

\section{Introduction}

Since the turn of the century, extreme wildfires, although still largely uncommon, have become more frequent in Australia, and in other countries. These fires include the many of the most damaging and high profile fires of recent times, including Canberra in 2003, Tasmania in 2013 and Victoria in 2003, 2006 and 2009. They manifest as large, unstoppable fires that couple with the atmosphere. They are also the source of pyrocumulonimbus clouds (pyroCbs or fire thunderstorms). Since 2001 there have been 56 confirmed pyroCb events in Australia.

We have formally defined an extreme wildfire (Sharples, et al., 2016) as one where one or more 
blow-up events occur before it is suppressed. Blow-up events are defined as instances when the fire switches from normal linear flaming to areal, or 'deep', flaming - over $5 \mathrm{~km}$ flaming depth has been observed. If this happens in an unstable atmosphere the fire can couple with the atmosphere (Potter, 2002), modifying the fire's behaviour. An example of deep flaming occurring during the 2013 Wambelong Fire can be seen in Figure 1. If deep flaming occurs in an atmosphere conducive to enhanced plume development, the plume can form a cloud before it mixes out. The release of the latent heat of condensation then further exacerbates the coupling between the fire and upper levels of the atmosphere, which can produce more erratic and unpredictable winds, facilitate the mixing down of drier air, increase the potential for ember transport, and produce dry lightning.

Arising from the extreme wildfires that hit Canberra on 18 January 2003 (Fromm, et al., 2006), a series of studies have provided insights into how these fires develop (Mills, 2005, 2008a \& 2008b, Fromm, et al. 2012, McRae, et al. 2015). In particular, they have highlighted the role of deep flaming events in combination with atmospheric conditions conducive to violent plume development. These insights have been drawn upon to develop a predictive model for blow-up fire events (McRae \& Sharples, 2013 \& 2014). The Blow Up Fire Outlook (BUFO) model incorporates insights into the triggers of deep flaming with measures of atmospheric instability. Deep flaming events are known to be caused by: two steady-state processes (strong winds and wind changes), a set of dynamic processes (vorticity-driven lateral spread, eruptive spread, dense spotting and fire coalescence), inappropriate use of ignition devices, and reburning of areas as new fuel becomes flammable with time.

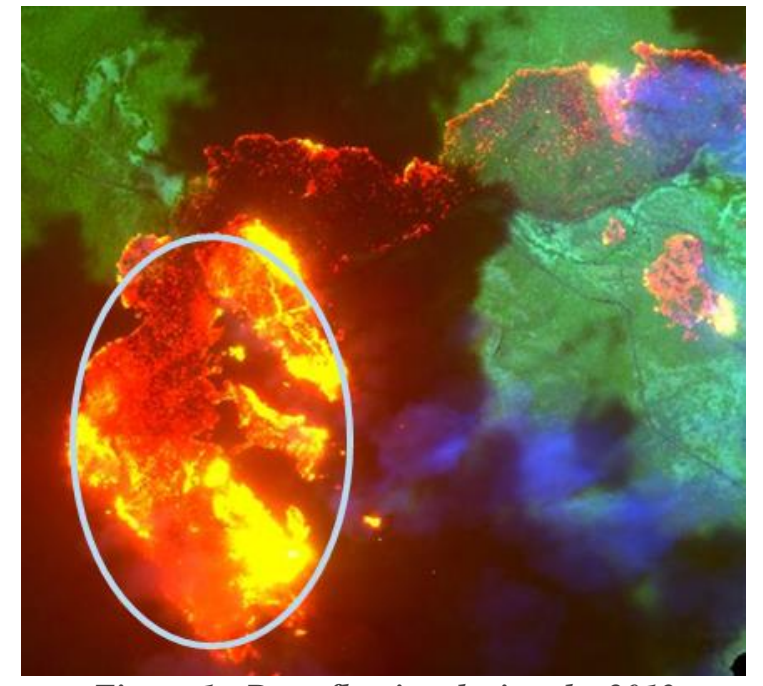

Figure 1 - Deep flaming during the 2013 Wambelong fire in NSW. The circled area exhibits widespread flaming in contrast to the more typical frontal fire behaviour that can be seen on other parts of the fire.

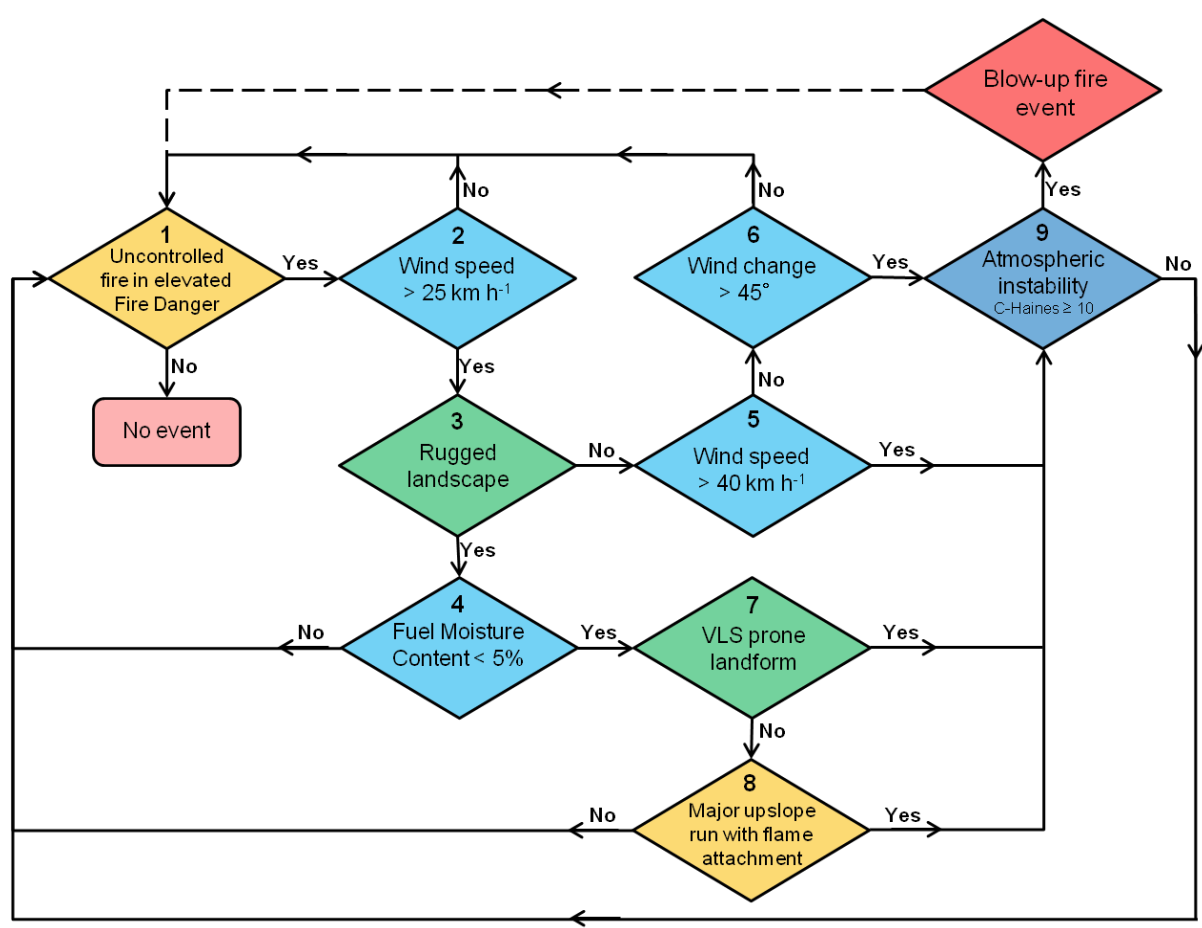

Figure 2 - Blow-Up Fire Outlook model flowchart. 
BUFO takes the form of a process model, which has recently been formally trialled. In this paper we provide an overview of the BUFO model and report on the outcome of the formal trial.

\section{The Blow-Up Fire Outlook (BUFO) model}

The BUFO model (Figure 2) takes the form of a decision tree, or flowchart. It comprises a series of questions leading from the start point, which concerns the occurrence of an uncontrolled fire on a day of elevated fire danger (i.e. hot, dry and windy surface weather). Each of the subsequent questions considers the setting of the fire and are formulated to provide a path dichotomy, with the "yes" option leading to further questions or to inferred occurrences of interest. The "no" option is used to loop back to allow re-running of the model at a future time (either to a schedule or when new information becomes available). The ultimate, inferred occurrence is that of a blow-up fire-event, and from there the model may be re-run at a future time. This loop-back is essential as some fire complexes may repeatedly blow-up. Examples of this include the 2003 and 2006 Victorian Alpine Complex and the West Fork (Colorado) Complex of July 2013.

In essence the model considers the likelihood of the fire exhibiting deep flaming in an atmospheric environment that is conducive to violent pyroconvective development of the plume. At present the atmospheric component of the model is assessed based on the continuous Haines index, with values over 10 being considered necessary for blow-up fire occurrence. However, in the future this component will likely be refined as a more comprehensive understanding of the influence of detailed frontal dynamics on plume development becomes available.

The model utilises weather forecast data from the Bureau of Meteorology, weather observations, terrain analysis data (e.g. available at www.highfirerisk.com.au), and fire information such as aerial linescans. It also makes heavy use of remotely-sensed information.

\section{Results of a formal trial}

The BUFO model was run in trial mode in the Australian Capital Territory and New South Wales between December 2013 and March 2016 (inclusive).

Table 1 - BUFO trial activity timeline. Only the last twelve months looked at areas outside of NSW/ACT.

\begin{tabular}{cccc} 
Month & $\begin{array}{c}\text { Assessments } \\
\text { undertaken }\end{array}$ & $\begin{array}{c}\text { NSW/ACT } \\
\text { Warnings }\end{array}$ & $\begin{array}{c}\text { NSW/ACT } \\
\text { Events }\end{array}$ \\
\hline Dec-13 & 1 & 0 & 0 \\
Jul-14 & 3 & 0 & 0 \\
Sep-14 & 2 & 0 & 0 \\
Oct-14 & 2 & 0 & 0 \\
Nov-14 & 4 & 1 & 0 \\
Dec-14 & 1 & 0 & 0 \\
Oct-15 & 2 & 0 & 0 \\
Nov-15 & 4 & 1 & 1 \\
Dec-15 & 3 & 0 & 0 \\
Jan-16 & 2 & 1 & 1 \\
Feb-16 & 1 & 0 & 0 \\
Mar-16 & 1 & 0 & 0
\end{tabular}

Over that period there were 23 days when the initial conditions for the model were met, or nearly met, and so warranted analysis. Overall, three alerts were issued. In two of these instances blow-up events were observed, while in one instance no blow-up eventuated. Therefore, the Probability of 
Detection was $100 \%$ and the False Alarm Rate was 33\%. The True Negative Rate, based on assessments made without an alert being issued and subsequently no blow-up event occurring, was $100 \%$. A future automated system would remove potential biases in the latter statistic, as all days could be assessed.

\subsection{Yarriman Road Fire (Pillaga), 26 November $2015\left(149.6^{\circ},-30.1^{\circ}\right)$}

A fire started in the Pilliga Scrub in New South Wales in the early afternoon. It was assessed with the BUFO model, as it was an uncontained wildfire under elevated Forest Fire Danger Index. The wind was over $25 \mathrm{~km} / \mathrm{hr}$, allowing various dynamic effects to potentially come into play. The landscape was flat, suggesting a wind driven elliptical fire with limited wind-terrain interactions. The winds were generally under $50 \mathrm{~km} / \mathrm{hr}$, but gusts exceeded that. A wind change was forecast to arrive midafternoon, which could produce deep flaming if a flank became a new, broader headfire. However gust winds could also produce deep flaming through high rates of spread. For either mechanism, the forecast Continuous Haines Index was 12, suggesting enough instability and dry air above the LCL to permit the fire to couple with the atmosphere.

This event shows the potential for a warning being issued with a useful lead-time being provided:

- 14:50 BUFO alert issued, with a review flagged for 17:00.

- 15:10 fire plume starts to show in Namoi weather radar.

- 15:30 radar reflectivity indicates enhanced pyroconvective activity, confirming a blow-up event (Figure 3).

- It is likely that the wind change arrived at 15:40.

- 18:40 radar reflectivity declines.

Therefore, the alert was able to be issued 40 minutes before the blow-up occurred. This was a true positive for the model. There were other fires in the trial area that caused operational concern, but for which the BUFO model did not indicate blow-up potential. None of these fires formed blow-ups events.

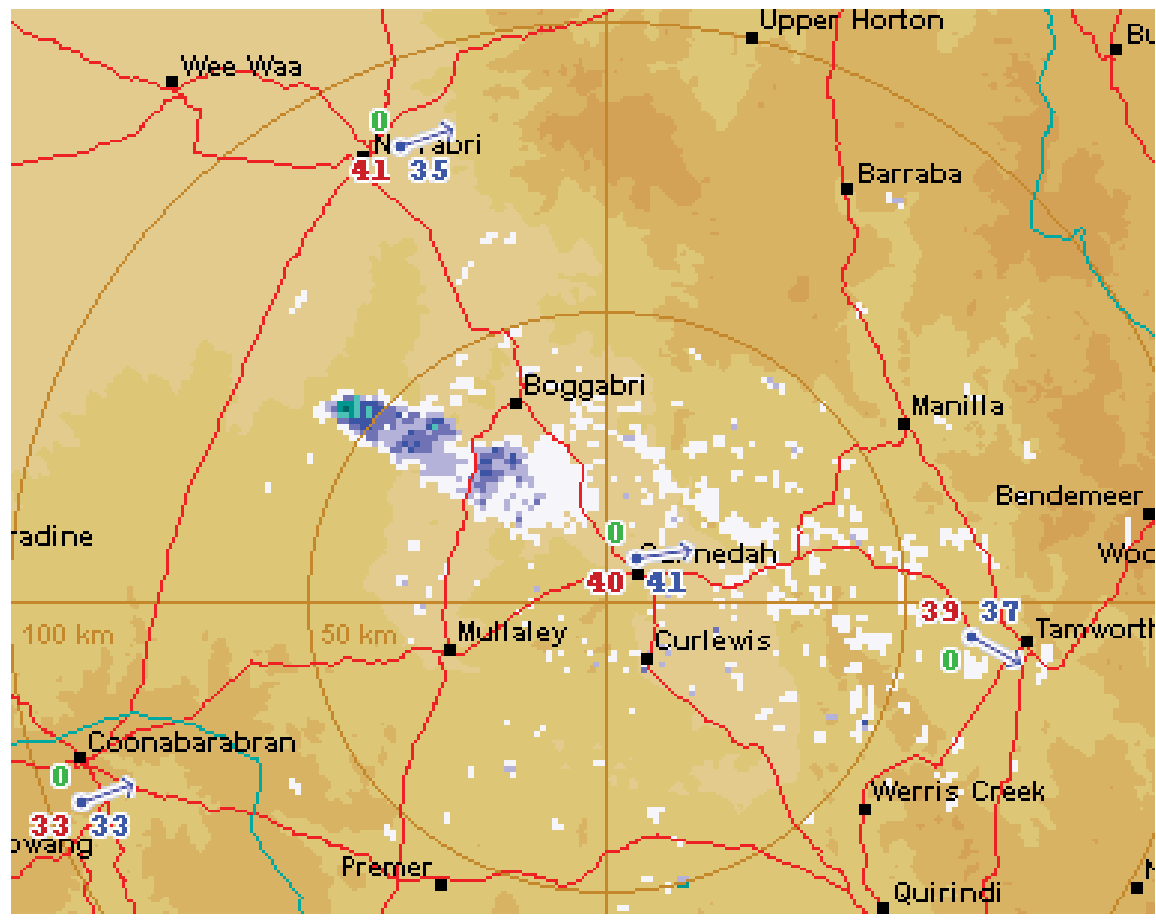

Figure 3 - Radar image of the plume of the Yarriman Road Fire showing partial $50 \mathrm{~km}$ and $100 \mathrm{~km}$ range rings. Image time: 16:00 AEDT (UTC+11); radar: Bureau of Meteorology, Namoi reflectivity. 


\subsection{Sir Ivan Fire, 11 February $2017\left(149.6^{\circ},-32.0^{\circ}\right)$}

After the trial had concluded, an operatonal BUFO alert was issued for a fire that went on to form a pyroCb the next day. It is believed that vorticity-driven lateral spread (Sharples, et al., 2012) was initiated along numerous sandstone cliffs in the area, further excerbated by passage of a trough overhead. The use of Himawari-8 satellite imagery at this fire was improtant, and suggested new aspects of violent pyro-convection that might be detected.

\section{Conclusion}

A useful level of skill has been demonstrated for anticipating fires that become blow-up events. The context, a landscape with elevated fire danger and a number of fires, can be analysed to identify where risks to the community and fire crews are most elevated. Subsequent work, outside the formal trial domain, indicates that broader implementation of the BUFO model will increase the likelihood of capturing future major wildfires and the threats that they pose. A holistic approach will provide more experience for practitioners and the ability to train on remote fires that pose little or no risk to the local community.

Most importantly, operational BUFO modeling promises to improve the ability of fire agencies to warn the community and their crews of potential threats from the most dangerous class of wildfires. Current best practice involves warnings to entire regions. There is promise of an ability to warn in a far more targeted manner, both spatially and temporally. Benefits of this could be far-reaching: avoiding loss-of-life (including avoiding tragedies on roads during evacuation); increasing the chance that warnings reflect real threats; and lessened community and economic impacts on a regional scale.

\section{Acknowledgements}

The authors are indebted to Laurence McCoy, NSW Rural Fire Service, who helped facilitate the operational trial of the model.

\section{References:}

Fromm M, Tupper A, Rosenfeld D, Servranckx R, McRae R, (2006) Violent pyro-convective storm devastates Australia's capital and pollutes the stratosphere. Geophysical Research Letters 33, L05815.

Fromm MJ, McRae RHD, Sharples JJ, Kablick GP (2012) Pyrocumulonimbus pair in Wollemi and Blue Mountains National Parks, 22 November 2006. Australian Meteorlogical and Oceanographic Journal, 62(3): 117-126.

McRae RHD, Sharples JJ (2013) A process model for forecasting conditions conducive to blow-up fire events. Proceedings, 2013 MODSIM Conference, Adelaide.

McRae RHD, Sharples JJ (2014) Forecasting conditions conducive to blow-up fire events. CAWCR Research Letters, 11, 14-19.

McRae R H D, Sharples JJ, Fromm M (2015) Linking local wildfire dynamics to pyroCb development. Natural Hazards and Earth Systems Sciences, 15, 417-428.

Mills, G.A. (2005) On the sub-synoptic scale meteorology of two extreme fire weather days during the Eastern Australian fires of January 2003. Australian Meteorological Magazine V54, pp: 265290.

Mills, G.A. (2008a). Abrupt surface drying and fire weather Part 1: overview and case study of the South Australian fires of 11 January 2005. Aust. Met. Mag. 57: 299-309. 
Mills, G.A. (2008b). Abrupt surface drying and fire weather Part 2: a preliminary synoptic climatology in the forested areas of southern Australia. Aust. Met. Mag. 57: 311-328.

Potter BE (2002) A dynamics based view of atmosphere-fire interactions. International Journal of Wildland Fire, 11, 247-255.

Sharples JJ, Cary GJ, Fox-Hughes P et al. (2016) Natural hazards in Australia: extreme bushfire. Climatic Change 139. doi:10.1007/s10584-016-1811-1.

Sharples, J.J., McRae, R.H.D. \& Wilkes, S.R. (2012). Wind-terrain effects on the propagation of wildfires in rugged terrain: fire channelling. International Journal of Wildland Fire, 21, 282-296 